\title{
ENSAIO SOBRE ESTELIONATO SENTIMENTAL: A POSSIBILIDADE DE RESPONSABILIZAÇÃO CIVIL EM RAZÃO DA EXPLORAÇÃO ECONÔMICA NAS RELAÇÕES DE NAMORO
}

\section{ARTIGO ORIGINAL}

SOUZA, Nathalia Verônica Pires de ${ }^{1}$

DIAS, Luciano Souto ${ }^{2}$

SOUZA, Nathalia Verônica Pires de. DIAS, Luciano Souto. Ensaio sobre Estelionato Sentimental: a possibilidade de responsabilização civil em razão da exploração econômica nas relações de namoro. Revista Científica Multidisciplinar Núcleo do Conhecimento. Ano 05, Ed. 06, Vol. 07, pp. 91-107. Junho de 2020. ISSN: 2448-0959, Link de acesso: https://www.nucleodoconhecimento.com.br/lei/estelionatosentimental

\section{RESUMO}

A pesquisa convida à reflexão sobre a possibilidade de responsabilização civil diante da ocorrência de exploração econômica nas relações de namoro, temática de inegável relevância, porém, pouco explorada no direito contemporâneo. É de se esperar que o período de namoro seja marcado por relação de lealdade e confiança entre os namorados, contudo, tornou-se comum o desrespeito a essas valorosa premissas, sobretudo diante de condutas que evidenciam intuito lucrativo, o que poderá, inclusive, justificar a provocação da tutela jurisdicional. À vista de tais observações, o presente

\footnotetext{
1 Pós-graduanda em Direito Tributário pela Pontifícia Universidade Católica de Minas Gerais - PUC Minas; Bacharela em Direito pela Faculdade de Direito do Vale do Rio Doce - Fadivale.

2 Doutorado em andamento em Ciências da Comunicação. Mestrado em Mestrado em Direito. Mestrado em Maestría En Derecho Internacional Público. Especialização em Direito Civil e Processual Civil. Graduação em Direito.
} 
ensaio aborda o estelionato sentimental, amparado em preceitos de caráter moral, jurídico-normativas e principiológicas, notadamente com ênfase nos princípios da dignidade da pessoa humana, boa-fé objetiva e afetividade, buscando, doravante, demonstrar os pressupostos para a configuração da possível responsabilidade civil. A pesquisa permite constatar que, uma vez configurado o estelionato sentimental e configurados os pressupostos legais, há possibilidade de responsabilização civil daquele que explorar economicamente as relações de namoro.

Palavras-chave: Estelionato sentimental, responsabilidade civil, possibilidade, indenização, boa-fé objetiva.

\section{INTRODUÇÃO}

Estelionato sentimental constitui temática recente no Direito contemporâneo, que tem dividido opiniões no tocante à sua configuração e eventuais consequências jurídicas. A ausência de previsão normativa, aliada à escassa bibliografia evidenciam a relevância da abordagem proposta nessa pesquisa, que compreende a reflexão quanto à possibilidade de responsabilização civil em razão da exploração econômica nas relações de namoro ou noivado.

As relações amorosas, que permitem a ampliação do conhecimento mútuo entre os envolvidos, o estreitamento de laços e a ampliação do convívio sentimental, comumente encontram firme pilar nas valorosas premissas da confiança, honestidade, honradez, respeito, e consideração mútua.

A convivência do casal no período de namoro não apresenta a affectio maritalis, que é a afeição conjugal ou o intuito de se constituir família e, outrossim não permite a configuração da união estável, em conformidade com o disposto no artigo 1.723 do Código Civil, contudo, o relacionamento apresenta características como estabilidade, convivência contínua, mútua confiança e a esperada lealdade.

Não obstante a expectativa positiva idealizada subjetivamente quanto à conduta do namorado ou namorada, em determinadas situações tem sido constatada verdadeira 
violação à esperada boa-fé na conduta durante o namoro, a partir de atitudes que evidenciam a intenção de se obter vantagem patrimonial, com as facilidades oferecidas em razão da confiança amorosa construída na relação.

Por conseguinte, mostra-se relevante a análise quanto à possibilidade de responsabilização civil pela exploração econômica nas relações de namoro, notadamente a partir do suporte em razões de ordem jurídica que sustentam essa hipótese. Razões de ordem moral, aliadas à conjuntura principiológica, jurisprudencial e normativa apontam para a possibilidade de responsabilização por eventual dano material e moral causado em virtude do aproveitamento da vinculação afetiva para aferição de vantagens de caráter patrimonial.

A questão do estelionato sentimental tem fundamentado demandas conduzidas ao Poder Judiciário, já sendo conhecida decisão condenatória envolvendo a restituição de valores referentes a empréstimos e a gastos realizados na constância do relacionamento.

Embora seja comum no cotidiano forense inúmeras demandas envolvendo situações de Direito de família, geralmente amparadas nas normas em vigor, o "estelionato sentimental" não conta com regramento específico positivado no ordenamento jurídico, o que exige a aplicação analógica de preceitos normativos que amparam a responsabilidade civil, em geral.

A pesquisa convida à reflexão quanto à configuração do estelionato sentimental nas relações de namoro, que até então não contam com proteção específica no ordenamento jurídico, bem como quanto à possibilidade de responsabilização civil diante de sua ocorrência. Ademais, o texto analisa os pressupostos para configuração do estelionato sentimental, em compatibilidade com os preceitos da responsabilidade civil.

As relações de namoro encontram amplo espaço na sociedade, sendo inegavelmente comuns à maioria das pessoas solteiras. Por conseguinte, é razoável que, diante de comprovados danos sofridos pela vítima a partir de condutas prejudiciais do namorado 
ou namorada, o sistema normativo, em proativa inovação, estenda sua proteção jurídica às relações de namoro, resguardando a possibilidade de ressarcimento de eventuais danos, de ordem material ou moral.

\section{ESTELIONATO SENTIMENTAL NAS RELAÇÕES DE NAMORO: CONFIGURAÇÃO E POSICIONAMENTO JURISPRUDENCIAL}

As relações de namoro, muito embora não sejam caracterizadas ou reconhecidas como entidade familiar, em certas ocasiões, vem produzindo implicações na seara jurídica, em especial no tocante à assistência material conferida a um namorado ao outro, no curso da relação, bem como em razão da possibilidade de reparação pelos danos materiais e morais decorrentes da responsabilidade civil (SENA, 2011).

O namoro é um relacionamento que precede e prepara para a consolidação de uma união estável ou formalização do matrimônio. Presume-se que existe fidelidade, lealdade e companheirismo entre os envolvidos, todavia, a partir do momento em que algum desses pilares é desrespeitado e um dos envolvidos, intencionalmente, passa a extrair vantagens do outro, aproveitando-se vínculo sentimental que os une, surge a possibilidade de responsabilização civil.

A expressão "estelionato" conta com tipificação criminal no artigo 171 do Código Penal (Decreto- Lei n. 2.848, de 7 de dezembro de 1940), que prescreve a conduta reprovada juridicamente nos seguintes termos: "Art. 171 - Obter, para si ou para outrem, vantagem ilícita, em prejuízo alheio, induzindo ou mantendo alguém em erro, mediante artifício, ardil, ou qualquer outro meio fraudulento:"

O crime de estelionato possui como característica a indução de alguém a uma falsa concepção de algo, com a finalidade de se adquirir benefício ilícito para si ou para outrem.

Em situações casuísticas nas quais, por exemplo, o namorado se valer da confiança do outro para utilização de cartão de crédito e aquisição de produtos, bens ou serviços, ou ainda quando ocorrer transferência de numerários para contas do namorado ou de 
terceiros, não havendo anuência ou conhecimento do namorado ou namorada que for vitimada, restará configurado o estelionato sentimental.

Nesse sentido, o penalista Greco (2014, p. 236) endossa que:

Desde que surgiram as relações sociais, o homem se vale de fraude para dissimular seus verdadeiros sentimentos, intenções, ou seja, para, de alguma forma, ocultar ou falsear a verdade, a fim de obter vantagens que, em tese, lhe seriam indevidas.

José Franklin de Souza entende que o termo "sentimental", pode definir uma ampla interligação a sentimento ou sensibilidade. No âmbito da psiquiatria forense, a denominação sentimental, "esta estritamente vinculada à capacidade de sentimentos positivos a outrem". (SOUZA, 2018, p.620)

O "estelionato sentimental" restará configurado quando, nas relações de namoro, um dos namorados obtiver, para si ou para outrem, vantagem ilícita, em prejuízo do outro namorado, induzindo-o ou mantendo-o em erro, mediante artifício, ardil, ou qualquer outro meio fraudulento"

Para Santos (2018, p. 03), o estelionato sentimental restará configurado "quando uma das partes tem a intenção de obter para si ou para outrem, vantagem ilícita em prejuízo alheio, incentivando ou mantendo alguém em erro, mediante artifício, como se fosse uma cilada/armadilha ou qualquer outro meio fraudulento."

Segundo Nelson Gonçalves (2014), o estelionatário sedutor é um ator, que estabelece relação sentimental com a vítima e até se põe no lugar dela para praticar golpes com requintes sentimentais. $O$ referido autor complementa:

Eles são falsários, pilantras, bandidos, criminosos como os demais ao pé da lei, mas a diferença é que praticam a fraude com requinte sentimental. E, para tanto, se valem de uma lábia vigarista que impressiona, por vezes, os mais criativos roteiristas de cinema (GONÇALVES, 2014, p. 01). 
De acordo com o entendimento de Hewdy Lobo, o estelionato sentimental:

É definido pelo fato de confiança amorosa entre um casal ao qual uma pessoa deste casal usa-se de meios ilícitos com a confiança do sentimento para que obtenha vantagens ilícitas para si ou para outrem. (LOBO, 2017, p.01)

O artigo 186 do Código Civil estabelece que aquele que, por ato ilícito, causar dano a outrem, fica obrigado a repará-lo. Doravante, o próprio Código Civil esclarece quanto ao ato ilícito, ao prever que aquele que, por ação ou omissão voluntária, negligência ou imprudência, violar direito e causar dano a outrem, ainda que exclusivamente moral, comete ato ilícito.

A expressão "estelionato sentimental" foi adotada como fundamento para decisão em ação judicial de cobrança, que tramitou em Brasília, autos ํo 2013.01.1.046795-0 (numeração única, CNJ no 0012574-32.2013.8.07.0001), na qual o juiz da 7 a Vara Cível, em sentença proferida dia 08 de setembro de 2014, condenou o réu a restituir à autora os valores que lhe foram transferidos, bem como à esposa daquele, no curso do relacionamento, que perdurou de junho de 2010 a maio de 2012, assim como os valores correspondentes às dívidas existentes em nome do réu e que foram pagas pela autora, conforme comprovado nos autos, e ainda os valores destinados ao pagamento de roupas e sapatos, comprovados nos autos e valores das contas telefônicas pagas pela autora. Ademais, condenou o réu ao pagamento das custas, despesas processuais e honorários advocatícios arbitrados em 10\% sobre o valor atualizado da condenação. Eis o conteúdo da publicação quanto à decisão proferida:

Tecidas estas considerações, ao tempo em que JULGO PARCIALMENTE PROCEDENTE o pedido formulado por [...] em face de [...], partes qualificadas nos autos, condeno o réu a restituir a autora: a) Os valores que the foram transferidos, bem como a sua esposa Sra. [...] (cf. Certidão de Casamento às f. 97 e transferência de f. 192), mediante transferência bancária oriunda da conta bancária da autora, no curso do relacionamento (junho de 2010 que perdurou até maio de 
2012), e que se encontram devidamente comprovados nos autos por intermédio dos documentos juntados às f. 190-220; b) Os valores correspondentes às dívidas existentes em seu nome (nome do réu) pagas pela autora conforme documentos de f. 138-140, f. 141-165 e f. 165-176); c) Os valores destinados ao pagamento da roupas e sapatos, comprovados às f. 43-44; e d) Os valores das contas telefônicas pagas pela autora, comprovados às f. 48-89. Referidos valores deverão ser corrigidos monetariamente pelo INPC, somados a juros de mora de $1 \%$ (um por cento) ao mês, ambos contados a partir de cada desembolso (Súmulas no 43 e 54 do Superior Tribunal de Justiça). Tendo a parte autora decaído de parte mínima do pedido (CPC, art. 21, parágrafo único), condeno o réu ao pagamento das custas, despesas processuais e dos honorários advocatícios que, atento as disposições normativas encampadas no § 3을 art. 20 do Código de processo Civil, fixo em 10\% sobre o valor atualizado da condenação. Transitada em julgado, intimando-se ao recolhimento das custas finais eventualmente em aberto, dê-se baixa e arquivem-se. Sentença registrada nesta data. Publique-se e intimem-se. Brasília - DF, segunda-feira, 08/09/2014 às 16h21. Luciano dos Santos Mendes, Juiz de Direito Substituto (DISTRITO FEDERAL, 2014, p. 01)

Foi interposto recurso de apelação pelo réu, tendo os autos sido distribuídos para a 5o Turma Cível do Tribunal de Justiça do Distrito Federal e Territórios, sob a relatoria do desembargador Carlos Rodrigues. No dia 19 de maio de 2015 foi publicada no Diário do judiciário a ementa do acordão, que negou provimento ao recurso, nos seguintes termos:

PROCESSO CIVIL. TÉRMINO DE RELACIONAMENTO AMOROSO. DANOS MATERIAIS COMPROVADOS. RESSARCIMENTO. VEDAÇÃO AO ENRIQUECIMENTO SEM CAUSA. ABUSO DO DIREITO. BOA FÉ OBJETIVA. PROBIDADE. SENTENÇA MANTIDA. 1. Deve ser mantida a sentença a quo eis que, da documentação carreada 
para os autos, consubstanciados em sua maior parte por mensagens trocadas entre as partes, depreendendo-se que a autora/ apelada efetuou continuadas transferências ao réu; fez pagamentos de dívidas em instituições financeiras em nome do apelado/réu; adquiriu bens móveis tais como roupas, calcados e aparelho de telefonia celular; efetuou o pagamento de contas telefônicas e assumiu o pagamento de diversas despesas por ele realizadas, assim agindo embalada na esperança de manter o relacionamento amoroso que existia entre os ora demandantes. Corrobora-se, ainda e no mesmo sentido, as promessas realizadas pelo varão-réu no sentido de que, assim que voltasse a ter estabilidade financeira, ressarciria os valores que obteve de sua vítima, no curso da relação. 2. Ao prometer devolução dos préstimos obtidos, criou-se para a vítima a justa expectativa de que receberia de volta referidos valores. A restituição imposta pela sentença tem o condão de afastar o enriquecimento sem causa, sendo tal fenômeno repudiado pelo direito e pela norma. 3. O julgador não está obrigado a pronunciar-se quanto a todos os dispositivos de lei invocados pelas partes, quando entender ser dispensável o detalhamento na solução da lide, ainda que deduzidos a título de prequestionamento. 4. Recurso conhecido e não provido. Decisão CONHECER. NEGAR PROVIMENTO. UNÂNIME (TJDF. Acórdão n.866800, 20130110467950APC, Relator: CARLOS RODRIGUES, Revisor: ANGELO CANDUCCI PASSARELI, 5a Turma Cível, Data de Julgamento: 08/04/2015, Publicado no DJE: 19/05/2015. P. 317) (DISTRITO FEDERAL, 2015, p. 317)

Na situação casuística vertente, o Tribunal compreendeu que os benefícios recebidos pelo réu foram adquiridos mediante a confiança obtida por meio de conduta ilícita, utilizando-se de artifícios para enriquecer de forma indevida. Com isso, negou-se provimento ao recurso, mantendo a sentença de forma integral. Conforme se depreende da decisão, o Tribunal de Justiça do Distrito Federal considerou como fundamentos da decisão a vedação ao enriquecimento sem causa, abuso do direito e boa-fé objetiva. 
É notório que existe grande desafio para se estabelecer requisitos, que comprovem o dano material sofrido pela vítima, tendo em vista ser comum, a ideia de ajuda econômica entre as partes no curso do relacionamento, entretanto, é necessário distinguir a ajuda mútua, dos danos materiais efetivamente causados.

\section{REPARABILIDADE CIVIL E SUA SUSTENTAÇÃO PRINCIPIOLÓGICA}

A obrigação de indenizar surge a partir da existência de uma ação ou omissão voluntária, relação de causalidade ou nexo causal, dano e culpa. Nesse sentido, o art. 186 do Código Civil estabelece que "Aquele que, por ação ou omissão voluntária, negligência ou imprudência, violar direito e causar dano a outrem, ainda que exclusivamente moral, comete ato lícito".

Gonçalves (2015, p. 501), define a palavra "responsabilidade" como "recomposição, obrigação de restituir ou ressarcir." Na responsabilidade civil, portanto, o prejudicado possui o direito de pleitear por uma reparação, buscando no patrimônio do ofensor, uma indenização moral ou material. (GONÇALVES, 2015, p.502)

De acordo com o posicionamento de Maria Helena Diniz:

A responsabilidade civil pressupõe uma relação jurídica entre a pessoa que sofreu o prejuízo e a que deve repará-lo, deslocando o ônus do dano sofrido pelo lesado para outra pessoa que, por lei, deverá suportá-lo, atendendo assim à necessidade moral, social e jurídica de garantir a segurança da vítima violada pelo autor do prejuízo. Visa, portanto, garantir o direito do lesado à segurança, mediante o pleno ressarcimento dos danos que sofreu, restabelecendo-se na medida do possível o status quo ante (DINIZ, 2014, p. 23-24).

Felipe Cunha de Almeida, ao rememorar ensinamentos de Sérgio Cavalieri Filho ressalta que o elementar sentimento de justiça assiste o interesse por buscar a obrigação do causador do dano à devida reparação. Por conseguinte, quando o ato 
ilícito gera um dano, ocorre o rompimento do equilíbrio jurídico-econômico que existia anteriormente entre o agente e a vítima. Diante disso, perdura-se uma necessidade de se ver restabelecido o equilíbrio quebrado, recolocando-se o status quo ante. (ALMEIDA, 2015, p.31)

O entendimento doutrinário no campo dos pressupostos da responsabilidade civil é vasto e divergente. Conforme Diniz (2014, p 54), esses pressupostos são de difícil caracterização, pois existe uma imensa imprecisão doutrinária.

Para melhor se entender tais pressupostos, adota-se o método utilizado por Gonçalves (2017, p.52) que, ao analisar o artigo 186 do Código Civil, esclarece a existência de quatro elementos essenciais da responsabilidade civil: ação ou omissão, culpa ou dolo do agente, relação de causalidade e o dano experimentado pela vítima.

A ação ou omissão refere-se a qualquer pessoa que, por conduta comissiva ou omissiva, venha causar dano a outrem.

As consequências jurídicas surgem no momento em que, uma ação ou omissão, advindas do comportamento humano voluntário exteriorizado provocam efeitos no âmbito jurídico. Em suma, a ação se dá por comportamento positivo, um fazer, diferentemente da omissão, que ocorre por não se fazer algo, por se abster em realizar um comportamento devido (CAVALIERI FILHO, 2014)

A configuração do estelionato sentimental pressupõe uma ação, ou seja, uma atitude de uma das partes, que provoque efeitos jurídicos.

No tocante ao requisito da culpa ou dolo do agente, tem-se que a existência do dolo compreende a ideia de infração, de intenção, de vontade, enquanto que a culpa, na falta de diligência, na negligência, imprudência ou imperícia. Destarte, o dolo referese a uma violação premeditada, consciente, voluntária do dever jurídico. (GONÇALVES, 2017)

Com relação a tal ponto, assevera o jurista Flávio Tartuce: 
O dolo constitui uma violação intencional do dever jurídico com o objetivo de prejudicar outrem. Trata-se da ação ou omissão voluntária mencionada no art. 186 do CC. Nos termos do que consta do art. 944, caput, do Código Civil, presente o dolo, vale a regra do princípio da reparação dos danos, o que significa que todos os danos suportados pela vítima serão indenizados. [...] $\mathrm{O}$ dolo, na responsabilidade civil, merece o mesmo tratamento da culpa grave ou gravíssima (TARTUCE, 2013, p. 445).

Cumpre salientar que a culpa é livre de qualquer elemento intencional, e ocorre por imprudência, negligência ou imperícia, o que não afasta o dever de reparar eventuais danos causados.

O elemento culpa, no entanto, não se mostra importante na análise da possibilidade de reparação civil nas relações de namoro, tendo em vista que a responsabilidade civil em tais relações deriva de ações premeditadas, conscientes e voluntárias, ou seja, nas quais restará configurado o dolo do agente.

Quanto ao requisito do nexo de causalidade entre fato e dano para a configuração do dever de indenizar, segundo Sílvio de Salvo Venosa, a relação de causalidade deriva das leis naturais, referindo-se ao vínculo que une a conduta do agente ao dano, ou seja, por meio da análise da relação causal que é possível identificar o causador do dano. "Se a vítima, que experimentou um dano, não identificar o nexo causal que leva o ato danoso ao responsável, não há como ser ressarcida." (VENOSA, 2012, p. 53)

Nesse sentido, Carlos Roberto Gonçalves reitera a ideia de Silvo Salvo Venosa, apontando como exemplo situação em que não existe nexo de causalidade entre a conduta do agente e o dano:

Se houve o dano, mas sua causa não está relacionada com o comportamento do agente, inexiste a relação de causalidade e também a obrigação de indenizar. Se, verbi gratia, o motorista está dirigindo corretamente e a vítima, querendo suicidar-se, atira-se sob as rodas do 
veículo, não se pode afirmar ter ele "causado" o acidente, pois na verdade foi um mero instrumento da vontade da vítima, esta sim responsável exclusiva pelo evento. (GONÇALVES, 2017 p. 54)

O nexo causal encontra-se como relevante aspecto a ser observado na solução de qualquer caso relacionado à responsabilidade civil, ou seja, é necessário apurar se o agente deu causa ao resultado (CAVALIERI FILHO, 2012).

A causalidade se faz presente no estelionato sentimental, considerando-se que o agente causador do dano possui uma relação intima com a vítima. Assim, a relação de confiança existente entre as partes refere-se ao vínculo que une a conduta do agente ao dano.

No tocante ao requisito do dano, não é possível responsabilizar alguém civilmente, sem que exista uma prova do dano, que se refere ao prejuízo sofrido, podendo ser individual ou coletivo, moral ou material (VENOSA, 2012)

Segundo Cavalieri Filho (2012, p. 77):

O dano encontra-se no centro da regra de responsabilidade civil. O dever de reparar pressupõe o dano e sem ele não há indenização devida. Não basta o risco de dano, não basta a conduta ilícita. Sem uma consequência concreta, lesiva ao patrimônio econômico ou moral, não se impõe o dever de reparar. $\mathrm{O}$ art. 927 do Código Civil é expresso nesse sentido: 'aquele que, por ato ilícito (arts. 186 e 187), causar dano a outrem, fica obrigado a repará-lo." O art. 186, por sua vez, fala em violar direito e causar dano.

Os danos patrimoniais carecem de comprovação por parte de quem os alega. Nesse campo, são amplas as manifestações doutrinárias e jurisprudenciais, com a interpretação de que não se pode reparar um dano hipotético ou eventual. A doutrina entende que o dano, como elemento da responsabilidade civil, necessita ser atual e certo (TARTUCE, 2018). 
No que se refere à indenização exclusivamente moral, não se pode dizer que ela possui unicamente a intenção de reparar o pretium doloris, no entanto, demanda restaurar a dignidade do ofendido. Em suma, o dano moral compreende uma lesão ao patrimônio psíquico da pessoa, à sua dignidade, afetando direitos da personalidade. Conforme ressalta Sílvio de salvo venosa, são danos de difícil avaliação monetária, não havendo uma base de equivalência específica quanto aos danos morais (VENOSA, 2012).

No âmbito das relações de namoro, o dano material pode ser constatado mormente por meio de comprovantes de transferências ou depósito de numerários, registros de conversas quanto às tratativas e promessa de pagamento, notas fiscais, fotografias e testemunhas. No que tange ao dano moral, restará configurado em razão da quebra da confiança que existia na relação, afetando diretamente a dignidade da vítima.

Diante dos pressupostos da responsabilidade civil retro expostos, é possível verificar que as condições inerentes ao referido instituto desencadeiam uma série de consequências para as partes envolvidas, sendo que, primeiramente uma ação (conduta) deverá ser praticada, em consequência desta ocorrerá uma lesão (dano) e, por fim, deverá ser verificada a existência de um vínculo entre a ação e o resultado, configurando a responsabilidade civil.

Diante disso, nas relações de namoro, quando uma das partes aproveita da relação de afeto para aferição de vantagens referentes ao patrimônio, surge então uma ação que lesionará a outra parte, cabendo assim, a possibilidade de reparação civil.

É oportuno consignar também a sustentação jurídica principiológica da reparabilidade civil em razão do estelionato sentimental.

O ordenamento jurídico conta com inúmeros princípios, que sustentam e equilibram a aplicação da norma jurídica. No presente estudo são considerados os princípios da dignidade humana, boa-fé objetiva e afetividade como diretrizes de sustentação da possibilidade de responsabilização civil por estelionato sentimental. 
O supra princípio da dignidade da pessoa humana constitui relevante fundamento na responsabilidade civil. Segundo Tartuce $(2013$, p. 303) "seria a personalização do Direito Civil, ou seja, a valorização da pessoa humana em detrimento do patrimônio".

Constitucionalmente, a dignidade da pessoa humana é reconhecida como um dos fundamentos da República Federativa do Brasil, como previsto no inciso III do art. $1^{\circ}$ (TAVARES, 2012, p. 584).

Acerca da temática, Moraes (2017, p. 41) afirma que:

A dignidade é um valor espiritual e moral inerente à pessoa, que se manifesta singularmente na autodeterminação consciente e responsável da própria vida e que traz consigo a pretensão ao respeito por parte das demais pessoas, constituindo-se um mínimo invulnerável que todo estatuto jurídico deve assegurar, de modo que, somente excepcionalmente, possam ser feitas limitações ao exercício dos direitos fundamentais, mas sempre sem menosprezar a necessária estima que merecem todas as pessoas enquanto seres humanos.

A compreensão quanto à dignidade humana pode sofrer influências históricas, religiosas e políticas, podendo apresentar variações nas diferentes jurisdições. $\mathrm{Na}$ prática, a dignidade humana apresenta duas faces, uma voltada para a filosofia, onde manifesta os valores morais que caracterizam todas as pessoas; outra, voltada para o Direito, onde traduz posições jurídicas titularizadas pelos indivíduos, tuteladas por normas coercitivas e pela atuação judicial. Em suma: a moral sob a forma de Direito (BARROSO, 2010).

Segundo Ricardo Mauricio Freire Soares, o princípio da dignidade da pessoa humana molda-se como base para diversos outros princípios:

Esse princípio da dignidade da pessoa humana permite reconstruir o modo de compreensão e aplicação dos direitos fundamentais no sistema jurídico brasileiro, potencializando a realização da justiça ao oportunizar: a aceitação da aplicabilidade direta e imediata dos direitos fundamentais; 
o reconhecimento da fundamentalidade dos direitos sociais de cunho prestacional; a inadequação dos conceitos de "reserva do possível" no constitucionalismo brasileiro; a aceitação da ideia de vedação ao retrocesso no campo dos direitos fundamentais; e a recusa a hipertrofia da função simbólica dos direitos fundamentais (SOARES, 2010, p.18).

Outrossim, à vista do estelionato sentimental nas relações de namoro, não se pode deixar de mencionar a relevância do aspecto afetivo. O afeto contribui pra a própria formação moral, social e psicológica da pessoa, impulsionando a autoestima. Por isso, é importante analisar o afeto, como direito fundamental pertencente à dignidade da pessoa humana (CARDIN e FROSI, 2010).

Outro princípio que merece destaque é o da boa-fé objetiva, uma das diretrizes norteadoras do Código Civil brasileiro. O referido caderno normativo inclusive prescreve, em seu artigo 113, que "os negócios jurídicos devem ser interpretados conforme a boa-fé e os usos do lugar de sua celebração".

Nessa perspectiva, tal princípio pertence ao direito privado, fundamentado na ideia da eticidade, pois representa um ideal de comportamento a ser praticado nas relações interpessoais. Nesse sentido, sendo fundado como princípio de natureza ética, "apresenta ele conexão com o princípio cardeal da dignidade da pessoa, albergado em sede constitucional e que permite ao sujeito uma condição de asseguramento dos anseios básicos" (LÊDO E MARQUESI, 2017, p.251).

Segundo o princípio da eticidade, a boa-fé ganhou significativa valorização no direito contemporâneo, ultrapassando o campo das ideias (boa-fé subjetiva), da intenção, passando a integrar no campo dos atos (boa-fé objetiva), das práticas de lealdade. Diante disso, a boa-fé objetiva é idealizada como uma forma de incorporação dos negócios jurídicos em geral, como instrumento auxiliar do aplicador do Direito para complementar lacunas, de espaços vazios deixados pelo legislador (TARTUCE, 2005, p.1) 
Conforme Antônio Lago Junior para se constatar se numa situação casuística restou obedecida a boa-fé objetiva, é preciso proceder ao seguinte questionamento: qual seria a conduta confiável e leal? Após resposta, deve-se questionar: a conduta do agente, no caso em análise, respeitou este padrão? Assim, a partir dessas duas respostas, é possível realizar uma análise se ouve ou não violação da boa-fé objetiva (JUNIOR, 2017, p.26)

No que se refere à boa-fé objetiva nas relações de casamento, o Código Civil, em seu artigo 1.566 prevê deveres de ambos os cônjuges. Flavio Tartuce aponta a relação de alguns desses deveres com o referido princípio:

O primeiro dever é o de fidelidade (art. 1.566, inc. I), que mantém relação direta com a boa-fé objetiva, entendida como uma conduta leal que deve existir entre as partes no negócio jurídico em questão. O segundo dever trata-se da mútua assistência (art. 1.566, inc. II), que também decorre da boa-fé, sendo entendida não só como assistência econômica, mas também assistência afetiva e moral. Mas, sem dúvida, o dever que mais mantém relação com o dever de lealdade é o de respeito e consideração mútuos (art. 1.566, inc. V). (TARTUCE, 2005, p. 6)

Impende salientar que embora o presente ensaio proceda à análise quanto à possibilidade de responsabilidade civil nas relações de namoro, é relevante observar em quais pontos o princípio da boa-fé objetiva se relaciona com os deveres consignados aos cônjuges, considerando a influência deles nessas relações.

À vista dessas considerações, o princípio da boa-fé objetiva não está somente vinculado aos contratos jurídicos, mas também em toda e qualquer relação que envolva indivíduos, de maneira que os atos ilícitos que provoquem danos à outrem devem ser evitados, porquanto podem gerar consequências capazes de implicar tanto na responsabilização civil quanto criminal.

O venire contra factum proprium se destaca na configuração do princípio da boa-fé objetiva. Farias e Rosenvald assim se pronunciam sobre a temática: 
O venire contra factum proprium (ou proibição do comportamento contraditório) evidencia de modo tão imediato a essência da obrigação de um comportamento conforme a boa-fé objetiva (ou seja, conforme o senso ético esperado de todos) que a partir dela é possível aferir a totalidade do princípio. Pois bem, a proibição do comportamento contraditório é modalidade de abuso de direito que surge da violação ao princípio da confiança decorrente da função integrativa da boa-fé objetiva (CC, art. 422). (FARIAS E ROSENVALD, 2016, p. 126)

O sistema normativo proíbe o comportamento capaz de frustrar a expectativa gerada entre as partes, pois tal frustração encaminha o lesado ao sofrimento das consequências do ato ilícito e, por conseguinte, conduz ao desequilíbrio da relação.

Nas relações de namoro, quando uma das partes utiliza da confiança como ferramenta para lesar a outra parte, não há que se negar a configuração de um comportamento que vai contra os ideais da boa-fé objetiva, restando configurado, portanto, um abuso de direito.

O princípio da boa-fé objetiva encontra amparo na eticidade, objetivando a segurança jurídica das relações sociais, a fim de evitar que qualquer das partes sofra prejuízos decorrentes de condutas alheias.

Resta destacar o princípio da afetividade que, de forma geral, abrange direitos relacionados à família, notadamente diante do afeto comum entre seus membros. $\mathrm{O}$ afeto representa sentimento de carinho que é solidificado entre as pessoas, na seara familiar e dos relacionamentos.

No âmbito da jurisdição moderna, o afeto pode ser incluído no rol dos direitos da personalidade, e vem sendo gradualmente reconhecido como valor jurídico decorrente dos princípios da solidariedade e da dignidade da pessoa humana (CARDIN e FROSI, 2010).

Conforme entendimento de Tartuce (2007, p. 12): 
O afeto talvez seja apontado, atualmente, como o principal fundamento das relações familiares. Mesmo não constando a palavra afeto no Texto Maior como um direito fundamental, podemos dizer que o afeto decorre da valorização constante da dignidade humana.

Arnaldo Rizzardo aborda a relevância da afetividade como valor protegido pela ordem jurídica:

De todos é conhecida a importância da afetividade, que envolve o vasto mundo de uma subjetividade decisiva na estrutura psíquica da pessoa, não podendo ser desligada de seu crescimento e formação. É incontestável que 0 afeto desempenha um papel essencial na vida psíquica e emotiva do ser humano. A afetividade é uma condição necessária na constituição do mundo interior (RIZZARDO apud ALMEIDA, 2015, p. 3).

Os laços de afeto e solidariedade derivam da coexistência em família, e de forma externa, entre famílias (ALMEIDA, 2015).

Considerando que a convivência gera afetividade, as questões referentes às relações de namoro também devem levar em conta o referido princípio.

Diante das considerações expostas, constata-se que é admissível o reconhecimento da existência de responsabilidade afetiva também nas relações de namoro.

\section{CONSIDERAÇÕES FINAIS}

A partir do exposto no presente ensaio é possível evidenciar reflexos da responsabilidade civil nas relações de namoro, notadamente no que tange à pretensão de reparação por eventuais danos causados, a partir da aplicação analógica da norma jurídica e com amparo em preceitos morais e nos princípios da dignidade da pessoa humana, boa-fé objetiva e afetividade. 
Embora as relações de namoro sejam caracterizadas por comportamentos que demonstram vinculação pessoal, publicidade e continuidade, ainda não contam com a adequada proteção do ordenamento jurídico.

Não seria adequado o ordenamento jurídico considerar o amor como um dever, contudo, a não obediência à boa-fé, notadamente a partir do reconhecimento do estelionato sentimental, deve ser enfrentada em conformidade com as premissas da responsabilidade civil, gerando, consequentemente, a obrigação de reparação de eventuais danos.

Decerto que a simples contribuição econômica entre os envolvidos na relação de namoro não gera sanção, devendo o Direito se atentar a comportamentos que evidenciam a quebra da boa-fé, lealdade e confiança existente na relação.

Eventual demanda judicial tendo como objeto a responsabilização civil envolvendo relações de namoro deve apresentar o máximo de provas capazes de demonstrar inequivocamente a configuração dos requisitos para a responsabilização civil.

O ordenamento jurídico não pode desprezar eventuais condutas dolosas lesivas à boa-fé nas relações de namoro que evidenciam quebra de confiança, abuso do direito e violação à boa-fé, podendo causar, inclusive, o enriquecimento sem causa daquele que se beneficiou economicamente de uma relação de namoro. O sistema normativo deve estender sua proteção às relações de namoro, se atentando à configuração do estelionato sentimental, bem como à possibilidade de sua reparação, o que poderá evitar condutas lesivas e resguardar os interesses das vítimas diante de eventuais injustiças.

\section{REFERÊNCIAS}

ALMEIDA, Felipe Cunha de. Responsabilidade Civil no Direito de Família: angústias e aflições nas relações familiares. Ed. Livraria do advogado. 2015. 
BARROSO, Luís Roberto. A Dignidade da Pessoa Humana no Direito Constitucional Contemporâneo: Natureza Jurídica, Conteúdos Mínimos e Critérios de Aplicação. 2010.

CARDIN, Valéria Silva Galdino; FROSI, Vitor Eduardo. Do afeto como valor jurídico. XIX Encontro Nacional do Conpedi - Fortaleza, Florianópolis: Fundação Boiteux, 2010.

CAVALIERI FILHO, Sergio. Programa de Responsabilidade Civil. 10 ed. São Paulo: Atlas, 2012.

CAVALIERI FILHO, Sergio. Programa de Responsabilidade Civil. 12 ed. São Paulo: Atlas, 2014.

DINIZ, Maria Helena. Curso de Direito Civil Brasileiro - Responsabilidade Civil, Vol. 7. 28 ed. São Paulo: Saraiva, 2014.

DISTRITO FEDERAL, Tribunal de Justiça. $7^{\text {a }}$ Vara Cível de Brasília. Sentença. Data da decisão: 08/09/2014. Luciano dos Santos Mendes, Juiz de Direito Substituto. Disponível em: http://cache-internet.tjdft.jus.br/cgibin/tjcgi1 ?MGWLPN=SERVIDOR1\&NXTPGM=tjhtml16\&ORIGEM=INTER\&CIRCUN $=1 \&$ SEQAND $=100 \&$ CDNUPROC $=20130110467950$. Acesso em 20 ago. 2019

DISTRITO FEDERAL. Tribunal de Justiça. 5 ${ }^{\mathbf{a}}$ Turma Cível. Acórdão n.866800, 20130110467950APC. Relator: CARLOS DIVINO VIEIRA RODRIGUES. Data de Julgamento: 08/04/2015. Publicado no DJE: 19/05/2015. P. 317. Disponível em: < https://pesquisadje-api.tjdft.jus.br/v1/diarios/pdf/2015/91.pdf\#page=0> Acesso em: 10 out. 2019

FARIAS, Cristiano Chaves de e ROSENVALD, Nelson. Curso de Direito Civil: Famílias. Vol. 6. Salvador: Editora Juspodium, 2016.

GONÇALVES, Carlos Roberto, Direito Civil Brasileiro - Parte Geral. Volume I - 13. ed. São Paulo: Saraiva, 2015. 
GONÇALVES, Carlos Roberto, Direito Civil Brasileiro - Responsabilidade Civil. Volume IV- 12 ed. - São Paulo: Saraiva, 2017.

GONÇALVES, Nelson. Como age o estelionatário sedutor? JCNET: São Paulo, 2014. Disponível em: < https://www.jcnet.com.br/Policia/2014/08/como-age-oestelionatario-sedutor.html> Acesso em: 19 jun. 2019.

GRECO, R. Curso de Direito Penal: parte especial, volume III. 11 Ed. Rio de Janeiro: Impetus, 2014.

JUNIOR, Antonio Lago. Ética e boa-fé no Direito - A operatividade da boa-fé objetiva nas relações obrigacionais. Editora Juspodvim, 2017. Disponível em: <https://www.editorajuspodivm.com.br/cdn/arquivos/17bad24b6ce77c0c8b431123fb6 835be.pdf> Acesso em: 16 ago. 2019

LÊDO, Ana Paula Silveira; MARQUESI, Roberto Wagner. O princípio da boa-fé objetiva como densificador da dignidade humana nas relações negociais. Londrinha: Scientia luris, 2017.

\section{LOBO, Hewdy. O que é Estelionato Sentimental e como a Psiquiatria Forense pode contribuir? 2017.2 Disponível em:} https://lobo.jusbrasil.com.br/artigos/417120168/o-que-e-estelionato-sentimental-ecomo-a-psiquiatria-forense-pode-contribuir. Acesso em 20 mai. 2020.

MORAES, Alexandre de. Direito constitucional. São Paulo: Atlas, 2017.

SANTOS, Fábio Celestino dos. Estelionato sentimental - quando o amor paga a conta: a exploração econômica no curso do namoro. Jurisway. 2018. Disponível em: https://www.jurisway.org.br/v2/dhall.asp?id_dh=19617. Acesso em: 20 mai. 2020

SENA, Ludmila Dantas. Reflexão sobre a dificuldade de distinção entre o namoro e a união estável no contexto jurídico atual. Monografia, Universidade Católica de Brasília, 03 de novembro de 2011. Disponível em: <https://docplayer.com.br/9483659- 
Reflexao-sobre-a-dificuldade-de-distincao-entre-o-namoro-e-a-uniao-estavel-nocontexto-juridico-atual.html> Acesso em: 20 mai. 2020.

SOARES, Ricardo Maurício Freire. O princípio constitucional da dignidade da pessoa humana: em busca do direito justo. 1. ed. São Paulo: Saraiva, 2010.

SOUZA, José Franklin de. Direito Privado, v 1. Ed. 2018.

TARTUCE, Flavio. O princípio da boa-fé objetiva no direito de família. Revista Brasileira de Direito de Família, 2005. Disponível em: <http://www.ibdfam.org.br/_img/congressos/anais/48.pdf> Acesso em: 20 ago. 2019

TARTUCE, Flavio. Manual de Direito Civil. Volume único. 8 ed. Rio de Janeiro: Forense, São Paulo: Método, 2018.

TARTUCE, Flavio. Direito civil: direito das obrigações e responsabilidade civil. Volume II. Rio de Janeiro: Forense, São Paulo: Método, 2013.

TARTUCE, Flavio. Novos princípios do direito de família brasileiro. 2007. Jus Navigandi, Teresina, ano, 10.

TAVARES, André Ramos Curso de direito constitucional. 10. ed. São Paulo: Saraiva, 2012.

VENOSA, Silvio de Salvo. Direito Civil - Responsabilidade Civil. 12 ed. São Paulo: Atlas, 2012.

Enviado: Maio, 2020.

Aprovado: Junho, 2020. 